\title{
Production, purification and characterization of a thermostable $\beta$-1,3-glucanase (laminarinase) produced by Moniliophthora perniciosa
}

\author{
AMANDA R. SENA ${ }^{1}$, GILDOMAR L.V. JÚNIOR ${ }^{1}$, ARISTÓTELES GÓES NETO ${ }^{1}$, ALEX G. TARANTO ${ }^{1}$, \\ CARLOS P. PIROVANI ${ }^{2}$, JÚLIO C.M. CASCARDO ${ }^{2 *}$, RUSSOLINA B. ZINGALI ${ }^{3}$, \\ MARCOS A. BEZERRA ${ }^{4}$ and SANDRA A. ASSIS ${ }^{1}$ \\ ${ }^{1}$ Departamento de Saúde, Universidade Estadual de Feira de Santana/UEFS, Avenida Transnordestina, s/n \\ Bairro Novo Horizonte, BR 116, 44036-900 Feira de Santana, BA, Brasil \\ ${ }^{2}$ Universidade Estadual de Santa Cruz/UESC, Rodovia Ilhéus-Itabuna, Km 16, 45650-000 Ilhéus, BA, Brasil \\ ${ }^{3}$ Universidade Federal do Rio de Janeiro, Instituto de Ciências Biomédicas, \\ Av. Carlos Chagas Filho, 373, CCS, Bloco H, $2^{\circ}$ andar, sala 08, Ilha do Fundão, 21941-590 Rio de Janeiro, RJ, Brasil \\ ${ }^{4}$ Universidade Estadual do Sudoeste da Bahia, Faculdade de Formação de Professores de Jequié \\ Rua José Moreira Sobrinho, s/n, Jequiezinho, 45201-190 Jequié, BA, Brasil \\ Manuscript received on September 15, 2010; accepted for publication on November 22, 2010
}

\begin{abstract}
The enzyme glucanase from Moniliophthora perniciosa was produced in liquid medium and purified from the culture supernatant. A multivariate statistical approach (Response Surface Methodology - RSM) was employed to evaluate the effect of variables, including inducer (yeast extract) and fermentation time, on secreted glucanase activities $M$. perniciosa detected in the culture medium. The crude enzyme present in the supernatant was purified in two steps: precipitation with ammonium sulfate $(70 \%)$ and gel filtration chromatography on Sephacryl S-200. The best inducer and fermentation time for glucanase activities were $5.9 \mathrm{~g} \mathrm{~L}^{-1}$ and 13 days, respectively. The results revealed three different isoforms (GLUI, GLUII and GLUIII) with purification factors of 4.33, 1.86 and 3.03, respectively. The partially purified enzymatic extract showed an optimum $\mathrm{pH}$ of 5.0 and an optimum temperature of $40^{\circ} \mathrm{C}$. The enzymatic activity increased in the presence of $\mathrm{KCl}$ at all concentrations studied. The glucanase activity was highest in the presence of $0.2 \mathrm{M} \mathrm{NaCl}$. The enzyme showed high thermal stability, losing only $10.20 \%$ of its specific activity after 40 minutes of incubation at $90^{\circ} \mathrm{C}$. A purified enzyme with relatively good thermostability that is stable at low pH might be used in future industrial applications.
\end{abstract}

Key words: glucanase, Moniliophthora perniciosa, production, kinetic characterization, purification, heat stability.

\section{INTRODUCTION}

The hemibiotrophic basidiomycete Moniliophthora perniciosa (Aime and Phillips-Mora 2005), the causative agent of witches' broom disease in Theobroma cacao, is responsible for major crop losses in South American and Caribbean cocoa plantations (Kilaru and Hasenstein 2005).

The disease shows two distinct stages: a biotrophic (intercellular monokaryotic mycelium) and a necro-

\footnotetext{
*In memoriam

Correspondence to: Sandra A. Assis

E-mail: sandraassis@uefs.com.br
}

trophic/saprotrophic phase (intracellular dikaryotic mycelium). The biotrophic mycelium depends on the host tissue for nutrients to sustain its growth and development.

A typical fungal cell wall is composed of chitin, glucans and proteins, and it can be degraded by chitinases and glucanases (Lin et al. 2007, Perez et al. 2002, Schirmbock et al. 1994). These enzymes are widely distributed among fungi, and some have been purified (Donzelli and Harman 2001).

$\beta$-glucan, a linear polysaccharide, is a principal cell wall component of cereal grains, including barley, rye, 
rice and wheat, and most of microorganisms in which it has multiple functions, including a role in nutrition. Structurally, $\beta$-glucans are comprised of $\beta$-1,3-, $\beta$-1,6and $\beta$-1,4-linked D-glucopyranosyl units (Planas 2000, Parrish et al. 1960). $\beta$-1,3-glucanase is an enzyme with strict cleavage specificity for $\beta$-1,3-linkages (Planas 2000).

The $\beta$-1,3-glucanases are classified as exo- $\beta-1,3-$ glucanase (EC 3.2.1.58) and endo- $\beta$-1,3-glucanase (EC 3.2.1.39) according to their mode of hydrolysis. Hydrolysis of $1,3-\beta$-linkages in the polysaccharide chain results in the release of short oligosaccharides. Exo- $\beta-1,3-$ glucanases remove glucose units from $\beta$-1,3-D-glucan by hydrolyzing terminal $\beta-1,3-\mathrm{D}$ linkages in a consecutive manner and produce D-glucose as the sole product (Pitson et al. 1993).

Enzymes that catalyze depolymerization or selective modification of cereal $\beta$-glucans are of biotechnological and biomedical importance because they have shown a significant potential application in malting and brewing processes (Konig et al. 2002, Mannonen et al. 1997), biological control of plant pathogens (De La Cruz et al. 1995), fungal and yeast cell wall degradation (Pitson et al. 1993), animal feed (Konig et al. 2002) and medical fields (Pang et al. 2005, Li et al. 2007).

To evaluate $M$. perniciosa as an industrial source of glucanase, the present study evaluated the influence of fermentation time and inducer on the activity of secreted glucanase from the fungus, using response surface methodology (RSM). Furthermore, the study describes the production, purification and characterization of $\beta$ 1,3-glucanase (laminarinase) from Moniliophthora perniciosa in saprotrophic phase mycelium.

\section{MATERIALS AND METHODS}

\section{Chemicals}

Laminarim and bovine serum albumin were purchased from Sigma (Sigma Chemical Co., St. Louis, MO, USA). All other chemicals used were of high-quality analytical grade.

\section{MicroorgANISM}

Moniliophthora perniciosa (CCMB 0257) was obtained from the Collection of Cultures of Microorganisms of Bahia (CCMB, Feira de Santana, Brazil). The fungus was maintained on potato dextrose agar at $28^{\circ} \mathrm{C}$ in an incubator (IGO 150 Cell Life - Jouan).

\section{Culture Conditions of Moniliophthora perniciosa}

Moniliophthora perniciosa was grown on potato dextrose agar for 10 days at $28^{\circ} \mathrm{C}$ to produce $\beta$-1,3-glucanase. Then, discs of fungal mycelium, with $1 \mathrm{~cm}$ in diameter, were taken from the solid culture, transferred into $100 \mathrm{~mL}$ erlenmeyer flasks containing liquid culture media with the following components dissolved in distilled water: wheat bran, $40.0 \mathrm{~g} \mathrm{~L}^{-1}$; yeast extract, 3.0$9.0 \mathrm{~g} \mathrm{~L}^{-1} ; \mathrm{K}_{2} \mathrm{HPO}_{4} 3 \mathrm{H}_{2} \mathrm{O}, 1.0 \mathrm{~g} \mathrm{~L}^{-1} ; \mathrm{MgSO}_{4} 7 \mathrm{H}_{2} \mathrm{O}$, $0.2 \mathrm{~g} \mathrm{~L}^{-1}$ and $\mathrm{KCl}, 0.2 \mathrm{~g} \mathrm{~L}^{-1}$. The incubation was carried out as described in the experimental design; flasks were heated at $28^{\circ} \mathrm{C}$ for 7 to 21 days and shaken at $120 \mathrm{rev} \min ^{-1}$ in a rotary shaker. The liquid culture medium, on which M. perniciosa was grown, was filtered and centrifuged (Centrifuge 5804R - Eppendorf, São Paulo, Brazil) at $8,000 \mathrm{~g}$ for $15 \mathrm{~min}$ at $4{ }^{\circ} \mathrm{C}$, and the supernatant, containing the proteins from $M$. perniciosa, was used as a crude enzymatic extract (Hua et al. 2007).

\section{DOEHLERT EXPERIMENTAL DESIGN FOR \\ ENZYME PRODUCTION}

Fermentation time and inducer concentration are among the most important parameters that affect the production of enzymes are fermentation time and inducer concentration (Giese et al. 2005). In this work, yeast extract was used as an inducer. To predict production of enzymes under any conditions of fermentation time and yeast extract concentration in the experimental domain, RSM was used. The Doehlert experimental design contained two variables, yeast extract and fermentation time, and three replicates at the center of the domain lead to a total of 9 experiments (Table I). Measurements were performed in triplicate to verify the best culture medium conditions to induce the production of $\beta-1,3$ glucanase. Yeast extract was studied at five concentrations, ranging from 3 to $9 \mathrm{~g} / \mathrm{L}$, and fermentation time was studied at three time points, ranging from 7 to 21 days. The experimental errors were evaluated from replication of a central point. The experimental data was processed using STATISTICA software. All the experiments in this step were carried out in random order.

Statistica version 7.0 was used to estimate the lack of fit of the model to the experimental data through analysis of variance (ANOVA). 
TABLE I

Doehlert matrix used for the optimization of 1,3-glucanase production from Moniliophthora perniciosa.

\begin{tabular}{c|c|c|c}
\hline Experiment & $\begin{array}{c}\text { Inductor concentration } \\
(\mathrm{g} / \mathrm{L})\end{array}$ & $\begin{array}{c}\text { Time } \\
(\text { days })\end{array}$ & $\begin{array}{c}\text { Enzyme activity } \\
(\mu \mathrm{mol} \text { glucose } / \mathrm{mL} / \mathrm{min})\end{array}$ \\
\hline 1 & $3(-1)$ & $14(0)$ & 0.1873 \\
2 & $4.5(-0.5)$ & $7(-0.866)$ & 0.1875 \\
$3(\mathrm{C})$ & $6(0)$ & $14(0)$ & 0.2026 \\
$4(\mathrm{C})$ & $6(0)$ & $14(0)$ & 0.2013 \\
$5(\mathrm{C})$ & $6(0)$ & $14(0)$ & 0.2007 \\
6 & $7.5(0.5)$ & $7(-0.866)$ & 0.1750 \\
7 & $9(1)$ & $14(0)$ & 0.1913 \\
8 & $4.5(-0.5)$ & $21(0.866)$ & 0.1722 \\
9 & $7.5(0.5)$ & $21(0.866)$ & 0.1766 \\
\hline
\end{tabular}

(C): central point; coded values are presented in parentheses.

\section{ENZYME PURIFICATION}

The purification procedure for $\beta$-1,3-glucanase from $M$. perniciosa involved the following two steps:

\section{Step 1: Ammonium sulfate precipitation}

The crude enzymatic extract previously obtained was brought to $70 \%$ saturation by adding solid ammonium sulfate and centrifuged at $10,000 \times \mathrm{g}$ for $10 \mathrm{~min}$ after standing for $1 \mathrm{~h}$. The precipitate, with high laminarinase activity, was resuspended in phosphate citrate buffer $(\mathrm{pH} 6.2)$ in the ratio of $1: 3(\mathrm{w} / \mathrm{v})$ and stored at low temperature.

\section{Step 2: Sephacryl S-200 chromatography}

The crude enzymatic extract was applied to a Sephacryl S-200 (Amersham Bioscience, USA) column (48 $\times$ $1.2 \mathrm{~cm}$ ) previously equilibrated with sodium phosphate buffer $\left(0.05 \mathrm{~mol} \mathrm{~L}^{-1}, \mathrm{pH} 7.0\right)$, which was also used to elute the product. Fractions of $1.5 \mathrm{~mL}$ were collected and assayed for glucanase activity. Fractions showing $\beta$-1,3-glucanase activity were pooled and concentrated by ultrafiltration using an Amicon PM 10 membrane, which has a molecular weight cut-off of $10 \mathrm{kDa}$.

\section{Protein Determination And EnZyme AnAlysis}

Protein concentration was determined by the method of Bradford (1976) using bovine serum albumin (BSA) as a standard. The enzyme activity of the purified $\beta$ 1,3-glucanase was measured using laminarin (from $\mathbf{L a}$ minaria digitata, Sigma) as the substrate. Laminarin was dissolved in $0.05 \mathrm{~mol} \mathrm{~L}^{-1}$ citrate buffer $(\mathrm{pH}$ 6.2). The reaction mixture contained $100 \mu \mathrm{L}$ of $0.1 \%$ laminarin and $100 \mu \mathrm{L}$ of enzyme solution. The mixture was incubated at $50^{\circ} \mathrm{C}$ for $15 \mathrm{~min}$. The reaction was stopped by the addition of $200 \mu \mathrm{L}$ of $1 \% 3,5$-dinitrosalicylic acid, and the mixture was boiled for $15 \mathrm{~min}$. The amount of reducing saccharides released from laminarin was measured spectrophotometrically (Cary 50 UV-Visible spectrophotometer, Varian Inc., São Paulo, Brazil) at $540 \mathrm{~nm}$ according to precedent (Miller 1959). One unit (U) of $\beta$-1,3-glucanase activity was defined as the amount of the enzyme required to release one microgram of glucose per minute under the above conditions.

\section{Heat Stability and Optimal PH AND TEmperature}

The optimal $\mathrm{pH}$ of $\beta$-1,3-glucanase activity was assayed at $\mathrm{pH}$ 5.0, 6.0, 7.0, 8.0, and 9.0. Blanks lacking glucanase were used in each determination.

To determine the optimum temperature, $\beta$-1,3-glucanase activity was tested under standard assay conditions in the temperature range of $30-90^{\circ} \mathrm{C}$. The temperatures were controlled using a circulating water bath.

To test the stability of the enzyme at elevated temperature, the samples of $\beta$-1,3-glucanase in test tubes of uniform size were incubated in water at different temperatures $\left(50,60,70,80\right.$ and $\left.90^{\circ} \mathrm{C}\right)$ and different amounts of time $(0,10,20,30,40,50$ and $60 \mathrm{~min})$. After heating, the tubes were cooled in an ice bath, and the residual activity measurement was carried out at a $\mathrm{pH}$ of 6.2 and at a temperature of $50^{\circ} \mathrm{C}$. 


\section{EFFECT OF CATIONS}

The effect of $\mathrm{Na}^{+}$and $\mathrm{K}^{+}$on $\beta$-1,3-glucanase activity was investigated. The following concentrations of both $\mathrm{NaCl}$ and $\mathrm{KCl}$ were used: $0.2,0.4,0.6,0.8$ and $1 \mathrm{~mol} \mathrm{~L}{ }^{-1} \cdot \beta-1,3$-glucanase activity was determined using the assay previously described, which uses laminarin as a substrate. An activity reading of $100 \%$ is obtained when no reagent is added.

\section{REPLICATIONS AND STATISTICAL ANALYSis}

The extractions and chromatographic isolations were repeated at least three times. Average values of triplicates (which differed by $<5 \%$ ) were calculated.

\section{RESULTS}

Production of $\beta$-1,3-GLUCANASE

A Doehlert matrix for two variables was applied to find the optimum conditions for the $\beta$-1,3-glucanase production from Moniliophthora perniciosa. The experimental results obtained with the Doehlert design for these variables together with the coded and real values for the variables studied are shown in Table II.

Below, Equation 1 illustrates the relationship between these two variables and the response $R$, in which $R$ is the enzyme activity, $I C$ is the inducer concentration and $T$ is the fermentation time:

$$
\begin{gathered}
R=0.108( \pm 0.008)+0.011 I C( \pm 0.002) \\
-0.0014 I C^{2}( \pm 0.0001)+0.0091 T( \pm 0.0006) \\
-0.00043 T^{2}( \pm 0.00002)+0.00040 I C \times T( \pm 0.00006)
\end{gathered}
$$

The corresponding surface response and level curves graphics for this equation are shown in Figures 1 and 2.

ANOVA has been applied using the experimental data to evaluate the quadratic model fitted. A test based on the Fisher distribution (F-test) has indicated that the fitted equation is statistically significant $(\mathrm{F}=24.65>$ 9.01). A lack-of-fit sum of squares $(\mathrm{F}=16.02<18.51)$ indicates that there is good agreement between the model's predicted response and the experimental values studied for each variable. Lagrange criterion applied to this equation indicates that the critical point is characterized as a maximum. The derivatization of this general equation as $\delta I C$ and $\delta T$ results in the following two new equations:

$$
\begin{aligned}
& \delta R=0.011-0.0028 I C+0.00040 T=0 \\
& \delta R=0.0091-0.00086 T+0.00040 I C=0
\end{aligned}
$$

The results showed that fermentation times longer than 18 days and shorter than 7 days caused a reduction in the amount of $\beta$-1,3-glucanase produced by $M$. perniciosa. Concentrations of yeast extract greater than $9 \mathrm{~g} \mathrm{~L}^{-1}$ and less than $3 \mathrm{~g} \mathrm{~L}^{-1}$ caused a decrease in the production of $\beta$-1,3-glucanase. Concentrations of yeast extract between 4 and $8 \mathrm{~g} \mathrm{~L}^{-1}$ and fermentation times between 8 and 17 days showed the highest concentrations of $\beta$-1,3-glucanase. The optimum activity of $0.2 \mu \mathrm{mol} \mathrm{min}^{-1} \mathrm{~mL}^{-1}$ was obtained using yeast extract concentration of $5.9 \mathrm{~g} \mathrm{~L}^{-1}$ and a fermentation time of 13 days (Figs. 1 and 2 ).

PurificAtion of $\beta$-1,3-GLUCANASE

The $\beta$-1,3-glucanase enzyme was purified by aqueous of M. perniciosa as described previously. After chromatography on Sephacryl S-200, it resulted in the separation of three peaks with $\beta$-1,3-glucanase activity, named GLUI, GLUII and GLUIII, with 4.33, 1.86 and 3.03-fold purification, respectively (Table III and Fig. 3).

\section{Heat Stability and Optimal PH ANd Temperature}

The $\beta$-1,3-glucanase from $M$. perniciosa was active between $\mathrm{pH} 5.0$ and $\mathrm{pH}$ 9.0, with maximum specific activity at pH 5.0 (Fig. 4). The effect of temperature on the specific activity of laminarinase is shown in Figure 5 . The maximum activity was obtained at $40^{\circ} \mathrm{C}$. The effect of temperature on the residual specific activity of glucanase is shown in Figure 5. $\beta$-1,3-glucanase retained $99.01,95.61$ and $92.38 \%$ of original activity after 50 min of incubation at 60,70 and $80^{\circ} \mathrm{C}$, respectively, and lost $10.20 \%$ of its specific activity after $40 \mathrm{~min}$ of incubation at $90^{\circ} \mathrm{C}$ (Fig. 6).

\section{EFFECT OF CATIONS}

The effects of $\mathrm{Na}^{+}$and $\mathrm{K}^{+}$ions on glucanase activity are shown in Figures 7 and 8. In the presence of $\mathrm{KCl}$, the glucanase activity was higher in the concentration of $0.40 \mathrm{~mol} \mathrm{~L}^{-1}$, showing an increase of $25 \%$ in the activity (Fig. 7), in relation to other analyzed concentrations. In the presence of $\mathrm{NaCl}$, the glucanase activity was higher in a $0.2 \mathrm{~mol} \mathrm{~L}^{-1}$ solution, showing an in- 
TABLE II

Analysis of variance for data presented in Table $I$.

\begin{tabular}{c|c|c|c|c|c}
\hline & $\mathrm{SS}$ & $\mathrm{df}$ & $\mathrm{MS}$ & $\mathrm{F}_{\text {cal }}$ & $\mathrm{F}_{\text {tab }}$ \\
\hline Regression & 0.00112757 & 5 & 0.00022551 & 24.65 & 9.01 \\
Residual & 0.00002745 & 3 & 0.00000915 & & \\
Lack-of-Fit & 0.00002440 & 1 & 0.00002440 & 16.02 & 18.51 \\
Pure Error & 0.00000305 & 2 & 0.00000152 & & \\
Total SS & 0.00115502 & 8 & & & \\
\hline
\end{tabular}

SS - sum of squares; df - degree of freedom; MS - mean square; $F_{c a l}-$ calculated $\mathrm{F}$ value; $\mathrm{F}_{\mathrm{tab}}$ - tabulated $\mathrm{F}$ value.

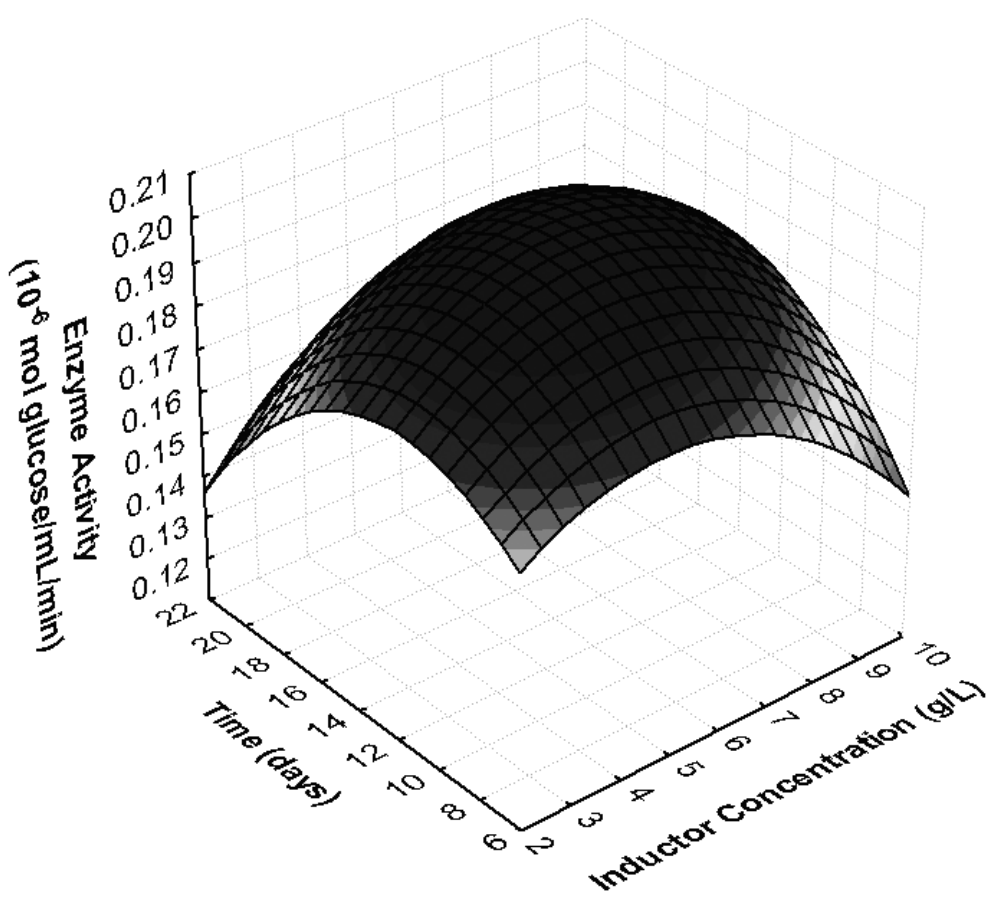

Fig. 1 - Response surface for inductor concentration versus incubation time.

TABLE III

Extraction and purification of $\beta$-1,3-glucanase.

\begin{tabular}{c|c|c|c|c}
\hline $\begin{array}{c}\text { Purification } \\
\text { step }\end{array}$ & $\begin{array}{c}\text { Activity Units } \\
(\mathrm{AU})\end{array}$ & $\begin{array}{c}\text { Protein } \\
\left(\mathrm{mg} \mathrm{mL}^{-1}\right)\end{array}$ & $\begin{array}{c}\text { Specific activity } \\
\left(\mathrm{AU} \mathrm{mg}^{-1} \text { protein }\right)\end{array}$ & $\begin{array}{c}\text { Purification } \\
\text { factor }\end{array}$ \\
\hline $\begin{array}{c}\text { Ammonium sulfate } \\
\text { precipitation } \\
\text { Sephacryl S-200 } \\
- \text { GluI } \\
\text { Sephacryl S-200 } \\
- \text { GluII } \\
\text { Sephacryl S-200 } \\
- \text { GluIII }\end{array}$ & 0.088 & $6.0 \times 10^{-2}$ & 1.47 & 1 \\
\hline
\end{tabular}




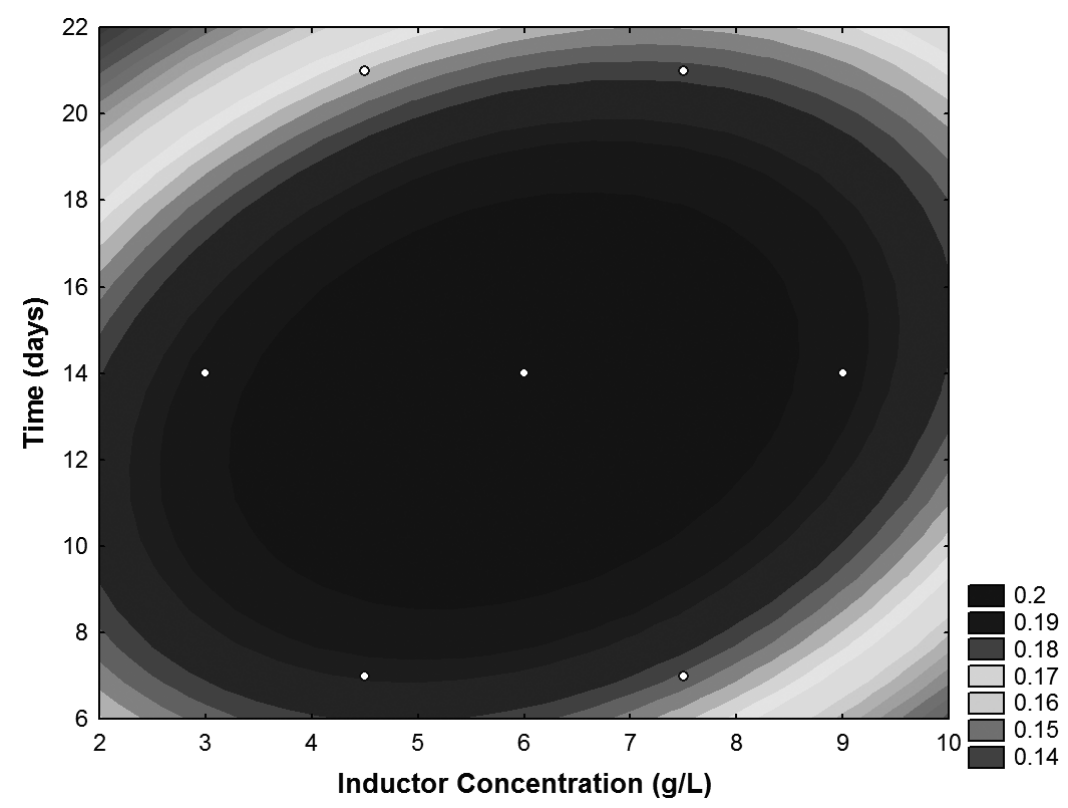

Fig. 2 - Isoresponse contour plot of inducer concentration versus fermentation time for $\beta$-1,3-glucanase.

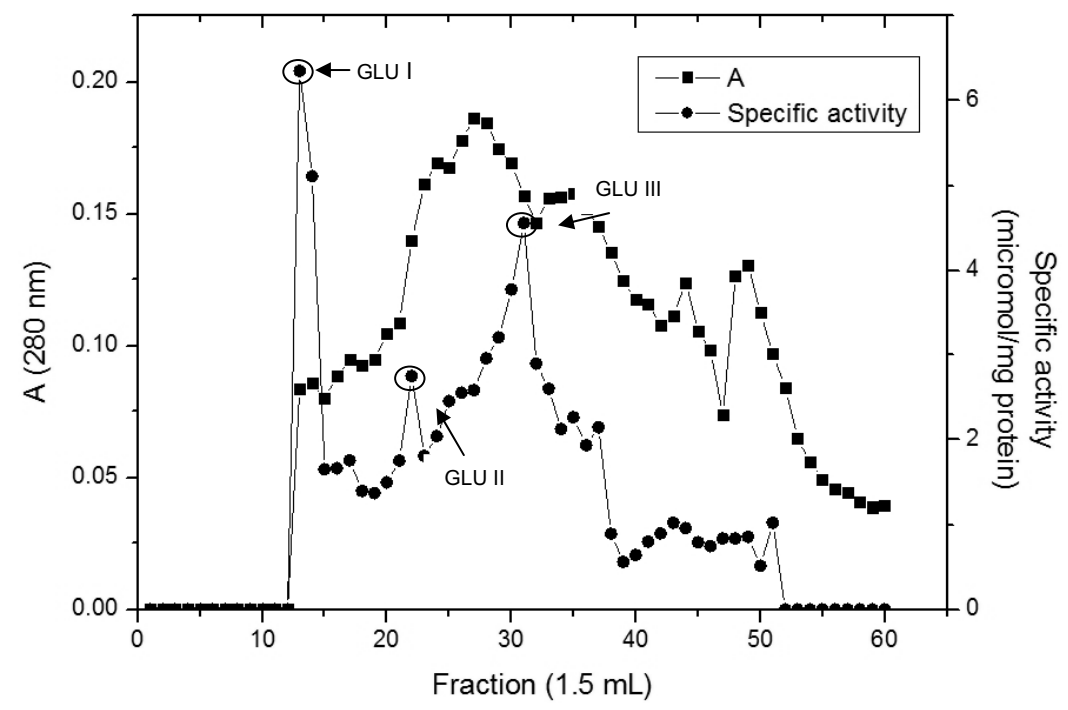

Fig. 3 - Purification of $\beta$-1,3-glucanase from M. perniciosa on Sephacryl S-200 column:

(ם) protein absorbance at $280 \mathrm{~nm}$; $(\bullet)$ specific activity.

crease of $8.83 \%$ in the activity (Fig. 8), also in relation to other concentrations studied for the same compound.

\section{DISCUSSION}

$\beta$-1,3-glucanase is one of the most important cell wall lytic enzymes. It has been purified from a number of fungal species in which the enzyme differs in its phys- iological properties, molecular structure, and molecular weight (McQuilken and Gemmell 2004). It was also speculated that the activity of the enzyme may vary due to the $\beta$-glucan structure and the type of linkage (Vazquez-Garciduenas et al. 1998). $\beta$-1,3-glucanase has been purified from many plant species, usually by multistep procedures that employ ion exchange columns followed by gel filtration and hydrophobic interaction. 


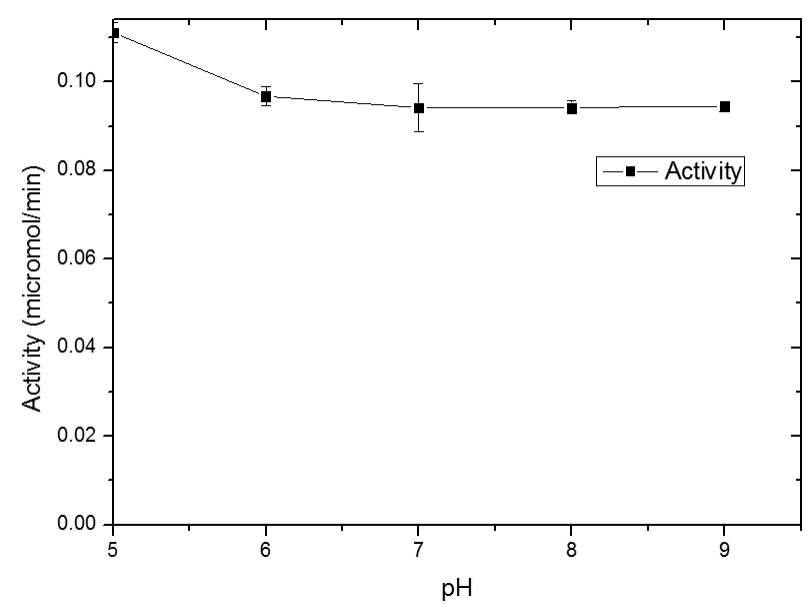

Fig. 4 -Effect of $\mathrm{pH}$ on the activity of the purified $\beta$-1,3-glucanase from M. perniciosa. The $\mathrm{pH}$ values were adjusted with the following buffer systems: citrate (5.0-6.0), phosphate (7.0) and Tris- $\mathrm{HCl}(8.0-9.0)$. The enzyme activity was measured at $50^{\circ} \mathrm{C}$ for $15 \mathrm{~min}$.

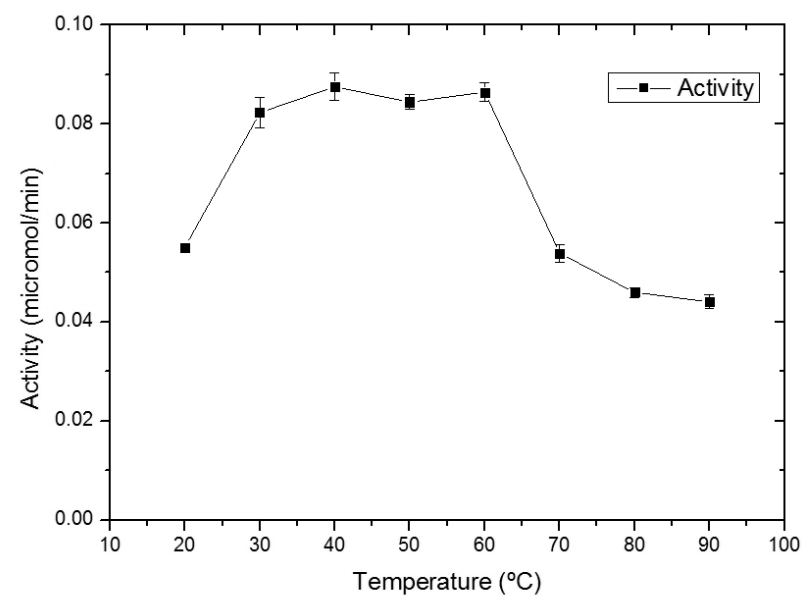

Fig. 5 - Effect of temperature on the activity of the purified $\beta$-1,3glucanase from $M$. perniciosa. All reactions were carried out in 0.05 mol L ${ }^{-1}$ of citrate buffer ( $\mathrm{pH}$ 6.2) for $15 \mathrm{~min}$. The temperatures tested ranged from $30-90^{\circ} \mathrm{C}$.

No previous studies could be found that describe the purification or characterization of a $\beta$-glucan degrading enzyme from M. perniciosa. The extracellular $\beta$-1,3-glucanases in the supernatant of the cell culture of $M$. perniciosa were partially purified and obtained in three isoforms, in which the optimal $\mathrm{pH}$ and temperature were 4.0 and $40^{\circ} \mathrm{C}$, respectively. The isozymes showed high thermal stability, losing only $10.20 \%$ of their specific activity after $40 \mathrm{~min}$ of incubation at $90^{\circ} \mathrm{C}$.

Murray et al. (2001) obtained a purification fold of 23.00 when they purified glucanase from Talaromy- ces emersonii by gel filtration, Hydrophobic Interaction Chromatography, and anion exchange. Boyce and Walsh (2007) obtained a purification fold of 9.00 when they purified glucanase using various purification steps. The $\beta$-1,3-glucanase from Periconia byssoides was purified by HiTrap Q XL, resulting in a purification fold of 4.50 .

Studying the influence of metal ions on the activity of the $\alpha$-1,3-glucanase showed that $\mathrm{K}^{+}$cations had an activating effect that was greater than that seen with $\mathrm{Na}^{+}$cations. 


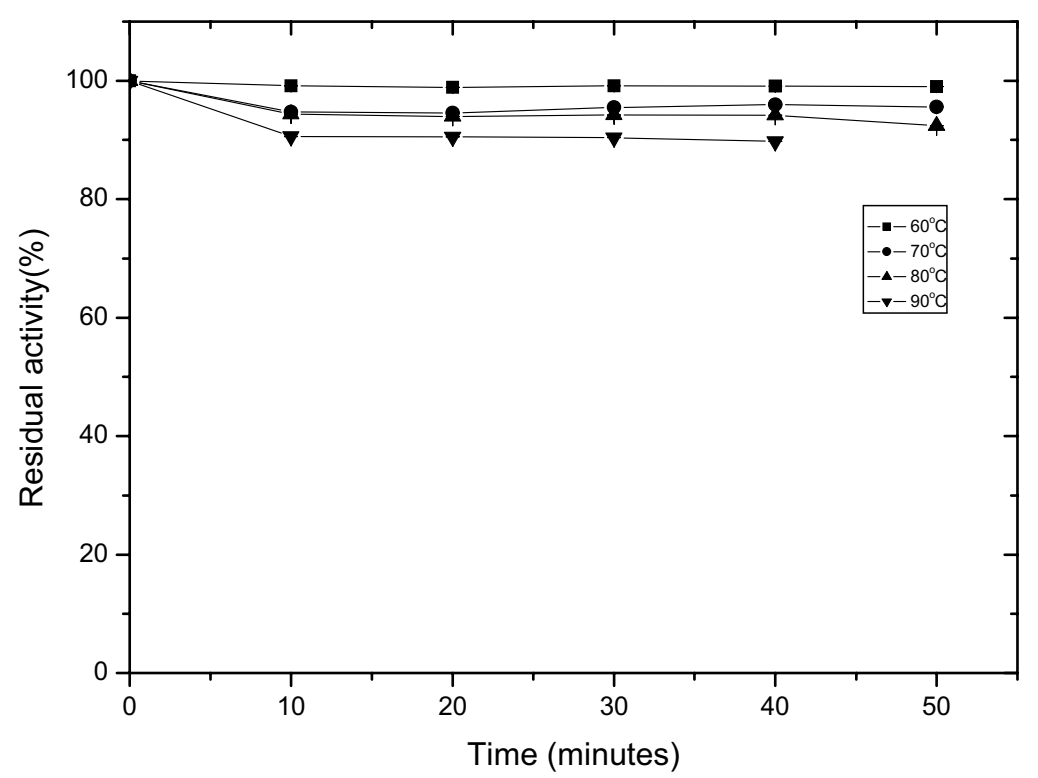

Fig. 6 - Effect of stability of the purified $\beta$-1,3-glucanase from $M$. perniciosa. All reactions were carried out in $0.05 \mathrm{~mol} \mathrm{~L}^{-1}$ citrate buffer ( $\mathrm{pH} \mathrm{6.2)} \mathrm{in} \mathrm{the} \mathrm{range} \mathrm{of} \mathrm{60-}$ $90^{\circ} \mathrm{C}$ for $15 \mathrm{~min}$. The percentage of residual $\beta$-1,3-glucanase activity was determined under standard assay conditions.

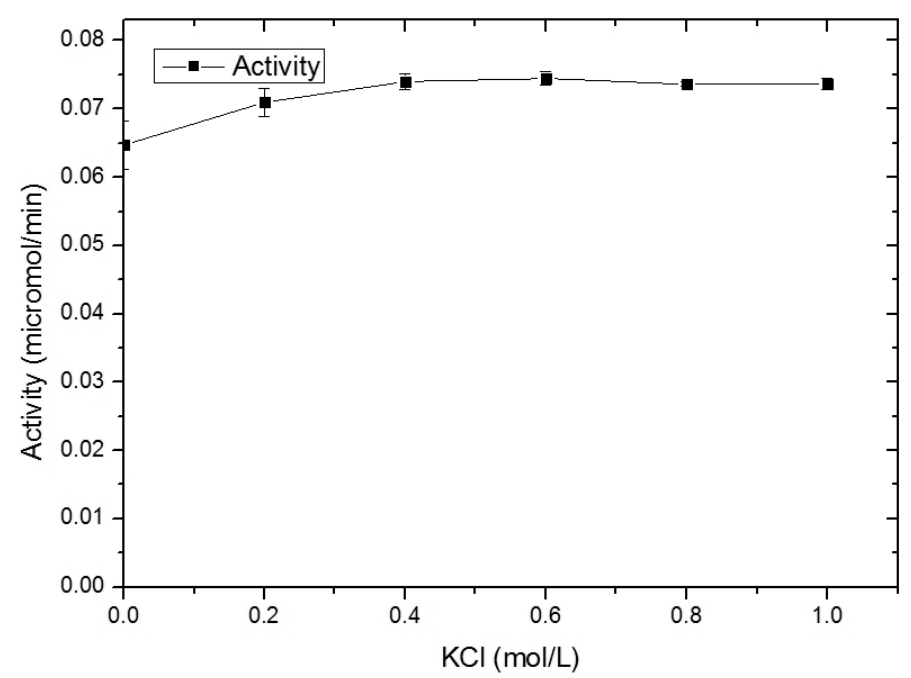

Fig. 7 - The effect of $\mathrm{KCl}$ on $\beta$-1,3-glucanase activity in the range of 0.2-1 mol $\mathrm{L}^{-1}$. All reactions were carried out in $0.05 \mathrm{~mol} \mathrm{~L}^{-1}$ citrate buffer $(\mathrm{pH} 6.2)$ at $50^{\circ} \mathrm{C}$ for $15 \mathrm{~min}$.

Notario et al. (1976) found that the $\beta$-1,3-glucanases are acidic proteins, and our results agree with theirs. Similar values of $\mathrm{pH}$ have been reported for $\beta$ 1,3-glucanases from other fungi, including Trichoderma harzianum (Marco and Felix 2007) and Trichoderma asperellum (Bara et al. 2003).
Optimal temperatures of $55-60^{\circ} \mathrm{C}, 45^{\circ} \mathrm{C}$, and $65^{\circ} \mathrm{C}$ were reported for $\beta$-glucanases from Bacillus polymyxa (Gosalbes et al. 1991), B. pumilis (Suzuki and Kancho 1976) and B. brevis (Louw et al. 1993), respectively. Similar values have been reported, but the optimum temperature of M. perniciosa was lower when compared to 


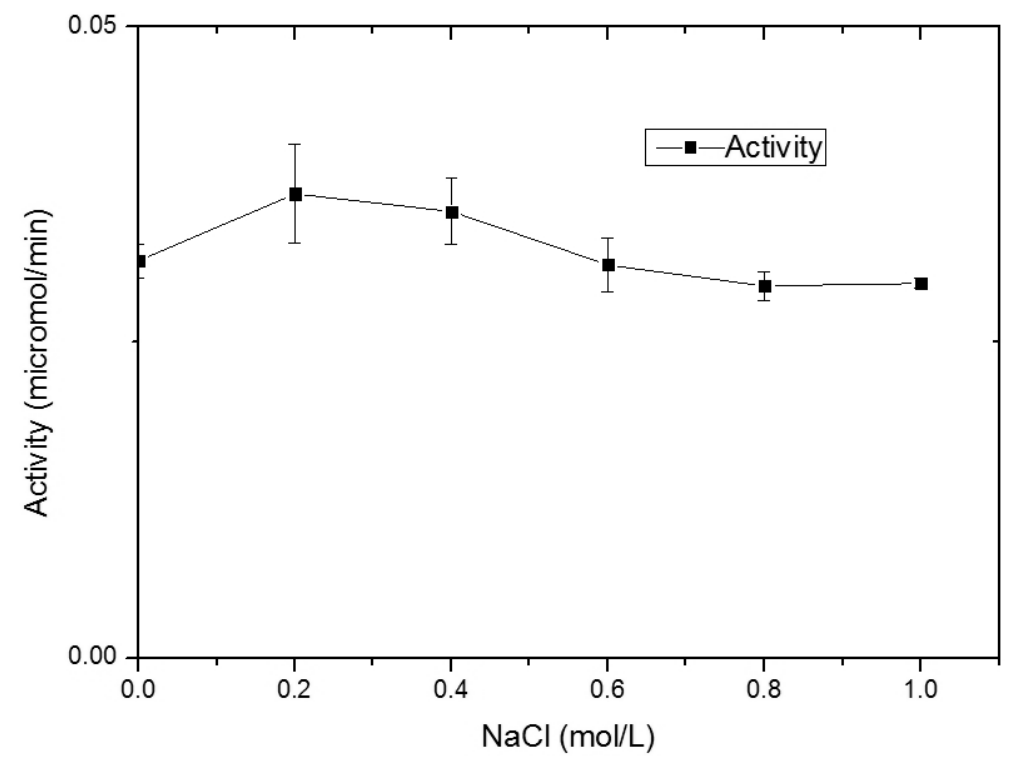

Fig. 8 - The effect of $\mathrm{NaCl}$ on $\beta$-1,3-glucanase activity in the range of $0.2-1 \mathrm{~mol} \mathrm{~L}^{-1}$. All reactions were carried out in $0.05 \mathrm{~mol} \mathrm{~L}^{-1}$ citrate buffer ( $\mathrm{pH} 6.2$ ) at $50^{\circ} \mathrm{C}$ for $15 \mathrm{~min}$.

most others (Nagata et al. 1990, Fontaine et al. 1997, Bara et al. 2003, Marco and Felix 2007, Li et al. 2007), and higher in relation to T. harzianum (Théodore and Panda 1995).

Murray et al. (2001) have also pointed out that the thermal stability of the $T$. emersonii enzyme is noteworthy because the estimated $\mathrm{t}_{1 / 2}$ values at $70^{\circ} \mathrm{C}$ and $80^{\circ} \mathrm{C}$ were $136 \mathrm{~min}$ and $25 \mathrm{~min}$, respectively, while $15 \%$ of the original activity remained after $15 \mathrm{~min}$ at $100^{\circ} \mathrm{C}$ in the absence of substrate. The $\beta-1,3$-glucanase of Agaricus brasiliensis was stable up to $50^{\circ} \mathrm{C}$ and showed a half-life of $30 \mathrm{~min}$ when incubated at $55^{\circ} \mathrm{C}$ (SHU et al. 2006). Low thermal stability was found at 45,50 and $60^{\circ} \mathrm{C}$ in Trichoderma harzianum (Marco and Felix 2007), and half-life values of 55, 21.5 and 5 minutes were found for the same enzyme in Chaetomium thermophilum, when incubated at 65,70 and $80^{\circ} \mathrm{C}$. This demonstrates the superiority of $\beta$-1,3-glucanase from $M$. perniciosa in comparison with the thermal stability of other fungi studied by other authors. Thus, $\beta-1,3-$ glucanase could be effective at the standard temperatures typically used for industrial processes.

The results of this study have shown that $M$. perniciosa could produce $\beta$-1,3-glucanase in the submerged culture, which contains three isoforms. The $\beta$-1,3-glucanases showed high thermostability and increased activity in the presence of $\mathrm{KCl}$, with concentrations vary- ing from 0.1 to $1.0 \mathrm{M}$. More studies are necessary to investigate the production of glucanases from M. perniciosa, to explore the possibility of molecular targets as a disease control for witches' broom, and to apply this enzyme in industrial processes.

\section{ACKNOWLEDGMENTS}

This work was supported by Financiadora de Estudos e Projetos (FINEP), Coordenação de Aperfeiçoamento de Pessoal de Nível Superior (CAPES), Conselho Nacional de Pesquisa (CNPq) and Fundação de Amparo à Pesquisa do Estado da Bahia (FAPESB).

\section{RESUMO}

A enzima glucanase de Moniliophthora perniciosa foi produzida em meio líquido e purificada a partir do sobrenadante da cultura. A metodologia de superfície de resposta (MSR) foi usada para avaliar os efeitos das variáveis, incluindo indutor (extrato de levedura) e tempo de fermentação, na atividade da glucanase de $M$. perniciosa detectada no meio de cultura. A enzima presente no sobrenadante foi purificada em duas etapas: precipitação com sulfato de amônio (70\%) e cromatografia de filtração em gel em Sephacryl S-200. A produção da enzima glucanase foi maior na concentração de $5,9 \mathrm{~g} \mathrm{~L}^{-1}$ de extrato de levedura e 13 dias de fermentação. Os resultados mostraram três diferentes isoformas (GLUI, GLUII e GLUIII) com fatores 
de purificação de 4,33, 1,86 e 3,03, respectivamente. O extrato enzimático parcialmente purificado mostrou um $\mathrm{pH}$ ótimo de 5,0 e uma temperatura ótima de $40^{\circ} \mathrm{C}$. A atividade enzimática aumentou na presença de $\mathrm{KCl}$ em todas as concentrações estudadas. A atividade da glucanase foi maior na presença de $\mathrm{NaCl}$ 0,2 M. A enzima apresentou alta estabilidade térmica, perdendo apenas $10,20 \%$ de sua atividade específica após 40 minutos de incubação a $90^{\circ} \mathrm{C}$. Os resultados de termoestabilidade e a atividade em baixo $\mathrm{pH}$ mostraram que a enzima glucanase de $M$. perniciosa tem características promissoras para futuras aplicações industriais.

Palavras-chave: glucanase, Moniliophthora perniciosa, produção, caracterização cinética, purificação, estabilidade térmica.

\section{REFERENCES}

Aime MC AND PhILliPs-MorA W. 2005. The causal agents of witches' broom and frosty pod rot of cacao (chocolate, Theobroma cacao) form a new lineage of Marasmiaceae. Mycologia 97: 1012-1022.

Bara MTF, Luna AL And UlhoA CJ. 2003. Purification and characterization of an exo- $\beta$-1,3-glucanase produced by Trichoderma asperellum. FEMS Microbiol Lett 129: 81-85.

Boyce A And Walsh G. 2007. Production, purification and application-relevant characterization of an endo-1,3(4)$\beta$-glucanase from Rhizomucor miehei. Appl Microbiol Biotechnol 76: 835-841.

BRADFORD MM. 1976. A rapid and sensitive method for the quantification of microorganisms quantities of protein utilizing the principle of protein-dye binding. Anal Biochem 72: 248-254.

De La Cruz J, Pintor-Toro JA, Benítez T, Llobell A AND Romero LC. 1995. A novel endo- $\beta$-1,3-glucanase, BGN13.1, involved in the mycoparasitism of Trichoderma harzianum. J Bacteriol 177: 6937-6945.

DONZELLI BG AND HARMAN GE. 2001. Interaction of ammonium, glucose, and chitin regulates the expression of cell wall-degrading enzymes in Trichoderma atroviride strain P1. Appl Environ Microbiol 67: 5643-5647.

Fontaine T, Hartland RP, Beauvais A, Diaquini M AND LATGE J-P. 1997. Purification and characterisation of an endo-1,3- $\beta$-glucanase from Aspergillus fumigatus. Eur J Biochem 43: 315-321.

Giese EC, Covizzi LG, Borsato D, DekKer RFH, Silva MLD AND BARBosA AM. 2005. Botryosphaeran, a new substrate for production of $\beta$-1,3-glucanases by Botryosphaeria rhodina and Trichoderma harzianum Rifai. Proc Biochem 40: 3783-3788.

Gosalbes MJ, Perezgonzales JA, Gonzales R and NAVARRo A. 1991. $2 \beta$-Glycanase genes are clustered in Bacillus polymuxa - Molecular cloning, expression and sequence analysis of genes encoding xylanase and an endo- $\beta$-(1,3)-(1,4)-glucanase. Journal Bacteriol 173: 7705-7710.

Hua Li, Jing Chen, Anna Li And Duo-Chuan Li. 2007. Purification and partial characterization of $\beta$ 1,3-glucanase from Chaetomium thermophilum. World J Microbiol Biotechnol 23: 1297-1303.

Kilaru A and Hasenstein KA. 2005. Development and Pathogenicity of the Fungus Crinipellis perniciosa on Interaction with Cacao Leaves. Biochemistry and cell biology. Phytopathology 95: 101-107.

Konig J, Grasser R, Pikor H And Vogel K. 2002. Determination of xylanase, $\beta$-1,3-glucanase and cellulase activity. Anal Bioanal Chem 374: 80-87.

Li H, Chen J, Li A And Li Duo-Chuan. 2007. Purification and partial characterization of $\beta$-1,3-glucanase from Chaetomium thermophilum. World J Microb Biot 23: 1297-1303.

Lin C, Yang J, Sun H, Huang X, Wang R And Zhang K. 2007. Purification and characterization of a $\beta-1,3-$ glucanase from the novel mycoparasite Periconia byssoides. Biotechnol Lett 29: 617-622.

Louw ME, REID SJ AND WATSON TG. 1993. Characterization, cloning and sequencing of a thermostable endo(1,3-1,4)- $\beta$-glucanase-encoding gene from an alkalophilic Bacillus brevis. Appl Microbiol Biotechnol 38: 507-513.

Mannonen L, Ritala A, NuUtila AM, Kurten U, AsPEgRen K, TeEri TH, Aikasalo R, TAmmisola J AND KAUPPINEN V. 1997. Thermo tolerant fungal glucanase in malting barley. In: Proceedings $26^{\text {th }}$ Congress European Brewery Convention, Maastricht, p. 91-100.

Marco JLM AND Felix CR. 2007. Purification and characterization of a $\beta$-glucanase produced by Trichoderma harzianum showin biocontrol potencial. Braz Arch Biol Techn 1: 21-29.

MCQUILKEN MP AND GEMMELL J. 2004. Enzyme production by the mycoparasite Verticillium biguttatum against Rhizoctonia solan. Mycopathology 157: 201-205.

Miller GL. 1959. Use of dinitrosalicylic acid reagent for determination of reducing sugar. Anal Chem 3: 426-428.

Murray PG, Grassick A, LAFFey CD, Cuff MM, Higgins T, SaVage AV, Planas A and Tuohy MG. 2001. Isolation and characterization of a thermostable 
endo- $\beta$-glucanase active on 1,3-1,4- $\beta$-D-glucans from the aerobic fungus Talaromyces emersonii CBS 814.70. Enz Microbial Technol 29: 90-98.

Nagata S, Sawatani M, Kuriyama M, Misono H and NAGASAKI S. 1990. Purification and characterization of nonlytic endo- $\beta$-1,3-glucanase I from Flavobacterium dormitator var. glucanolyticae. Agr Biol Chem Tokyo 54: 2107-2114.

Notario V, Villa TG and Villanueva JR. 1976. Purification of an exo- $\beta$-D-glucanase from cell-free extracts of Candida utilis. Biochem J 159: 555-562.

PANG Z, Otaka K, MaOKa T, Hidaka K, IshiJima S, OdA M AND OHNishi M. 2005. Structure of $\beta$-glucan oligomer from laminarin and its effect on human monocytes to inhibit the proliferation of U937 cells. Biosci Biotechnol Biochem 69: 553-585.

PARrish FW, PERlin AS AND ReESE ET. 1960. Selective enzymolysis of poly- $\beta$-D-glucan and structure of the polymers. Can J Chem 38: 2094-2104.

Perez LM, Besoain X, Reyes M, Pardo G and MonTEALEGRE J. 2002. The expression of extracellular fungal cell wall hydrolytic enzymes in different Trichoderma harzianum isolates correlates with their ability to control Pyrenochaeta lycopersici. Biol Res 35: 401-410.

Pitson S, Seviour R And McDougall B. 1993. Noncellulolytic fungal $\beta$-glucanases: their physiology and regulation. Enz Microbial Technol 15: 178-192.
Planas A. 2000. Bacterial 1,3-1,4- $\beta$-glucanases: structure, function and protein engineering. Biochimica el Biophysica 1534: 361-382.

SCHIRMBOCK M, LORITO M, WANG YL, HAYES CK, ARISAN-ATAC I, SCALA F, HARMAN GE AND KUBICEK CP. 1994. Parallel formation and synergism of hydrolytic enzymes and peptaibol antibiotics, molecular mechanisms involved in the antagonistic action of Trichoderma harzianum against phytopathogenic fungi. Appl Environ Microbiol 60: 4364-4370.

Shu ChIn-Hang, Xu Chun-Jun And Lin EN-ShU. 2006. Production, purification and partial characterization of a novel endo- $\beta$-1,3-glucanase from Agaricus brasiliensis. Process Biochem 41: 1229-1233.

SuzuKi H AND Kancho T. 1976. Degradation of barley glucan and lichenin by a Bacillus pumilis enzyme. Agri Biol Chem 40: 577-586.

THÉODORE K AND PANDA T. 1995. Application of response surface methodology to evaluate the influence of temperature and initial ph on the production of $\beta$-1,3-glucanase and carboxymethylcellulase from Trichoderma harzianum. Enzyme Microb Tech 17: 1043-1049.

Vazquez-Garciduenas S, Leal-Morales CA AND Herrera-Estrella A. 1998. Analysis of the $\beta$-1,3glucanolytic system of the biocontrol agent Trichoderma harzianum. Appl Environ Microbiol 64: 1442-1446. 